\title{
Risk for friction injury in long-lived elderly in primary health care
}

Risco para lesão por fricção em idosos longevos na atenção primária à saúde

Riesgo de lesión por fricción en adultos mayores longevos en la atención primaria de salud

Francisco Reis Tristão', Juliana Balbinot Reis Girondi², Karina Silveira de Almeida Hammerschmidt², Cilene Fernandes Soares ${ }^{3}$, Tatiana Martins ${ }^{4}$, Daniella Karine de Souza Lima

ORCID IDS

Tristão FR (D) https://orcid.org/0000-0003-1451-4566

Girondi JBR (D) https://orcid.org/0000-0003-0271-259X

Hammerschmidt KSA (D) https://orcid.org/0000-0002-7140-3427

Soares CF (iD https://orcid.org/0000-0002-6032-8644

Martins T (D) https://orcid.org/0000-0002-2475-0653

Lima DKS (iD https://orcid.org/0000-0001-7167-0907
HOW TO CITE

Tristão FR, Girondi JBR, Hammerschmidt KSA, Soares CF, Martins T, Lima DKS. Risk for friction injury in long-lived elderly in primary health care. ESTIMA, Braz. J. Enterostomal Ther., 16: e3218. https:// doi.org/10.30886/estima.v16.614.

Manuscript extracted from the results of a monograph entitled "Risk stratification for the occurrence of friction injury and pressure injury in elderly in the community", by Francisco Reis Tristão, referring to the Specialization Course in Health Care for Elderly, Universidade Federal de Santa Catarina, 2016.

\begin{abstract}
Objective: To identify the risks for the development of friction injury (FI) in long-lived elderly in primary health care. Methods: Descriptive research of quantitative approach. Participants were 42 elderly aged 80 years or more. Conducted structured interview and applied form. Simple descriptive analysis was realized by means of the absolute and relative frequency of the variables. Verified the level of significance between the most frequent clinical factors and sociodemographic factors: age, ethnicity and gender, using the chi-square test or Fisher's exact test. The contingency coefficient was performed with the parameters: $c \geq 0.750=$ strong association; 0.500 to 0.749 = moderate association; $\leq 0.499$ = weak association. Results: Age ranged from 80 to 100 years, prevailing between 80 and 85 years (59.5\%), 28 (66.7\%) women, 38 (90.5\%) white and 30 (71.4\%) with incomplete first degree. In 41 elderly patients (97.6\%), there were dermatological alterations related to the risk for Fl (dry skin, senile blemish, ecchymosis and edema). Age was the demographic factor with the highest association with clinical findings ( $p=0.0397)$. Conclusion: Faced with these findings, it becomes imperative that nurses be equipped with scientific knowledge, which allow them to propose care capable of controlling the risk factors for Fl development.
\end{abstract}

DESCRIPTORS: Geriatric nursing; Nursing care; Primary health care; Elderly with 80 years or more; Stomatherapy.

\footnotetext{
'Secretaria Municipal de Saúde de São José - Diretoria de Atenção Primária à Saúde - São José/SC - Brazil.

¿Universidade Federal de Santa Catarina - Departamento de Enfermagem - Florianópolis/SC - Brazil.

${ }^{3}$ Secretaria Municipal de Saúde de Florianópolis - Diretoria de Administração - Florianópolis/SC - Brazil.

${ }^{4}$ Universidade Federal de Santa Catarina - Programa de Pós-Graduação em Enfermagem - Florianópolis/SC - Brazil.

Corresponding author: Tatiana Martins | Avenida Madre Benvenuta, 40 - Santa Mônica | CEP: 88036-500 - Florianópolis/SC - Brazil |

E-mail: tatiana_martins15@hotmail.com

Received: June 142018 | Accepted: Oct. 202018
} 


\section{RESUMO}

Objetivo: Identificar os riscos para o desenvolvimento de lesão por fricção (LF) em idosos longevos na atenção primária à saúde. Métodos: Pesquisa descritiva de abordagem quantitativa. Participaram 42 idosos com idade igual ou superior a 80 anos. Realizada entrevista estruturada e aplicado formulário. Realizada análise descritiva simples por meio da frequência absoluta e relativa das variáveis. Verificado o nível de significância entre os fatores clínicos de maior frequência e fatores sociodemográficos: idade, etnia e gênero, utilizando o teste qui-quadrado ou exato de Fisher. Efetuou-se o coeficiente de contingência com os parâmetros: $c \geq 0,750$ = associação forte; 0,500 a 0,749 = associação moderada; $\leq$ 0,499 = associação fraca. Resultados: A idade variou de 80 a 100 anos, prevalecendo entre 80 e 85 anos (59,5\%), 28 (66,7\%) do sexo feminino, 38 (90.5\%) da raça branca e 30 (71,4\%) com primeiro grau incompleto. Em 41 idosos (97.6\%), observaram-se alterações dermatológicas relacionadas ao risco para LF (pele seca, mancha senil, equimose e edema). A idade foi o fator demográfico com maior associação aos achados clínicos ( $p=0,0397)$. Conclusão: Frente a esses achados, torna-se imperativa a necessidade de o enfermeiro munir-se de conhecimentos científicos, os quais permitem propor cuidados capazes de controlar os fatores de risco para desenvolvimento de LF.

DESCRITORES: Enfermagem geriátrica; Cuidados de enfermagem; Atenção primária à saúde; Idoso de 80 anos ou mais; Estomoterapia.

\section{RESUMEN}

Objetivo: Identificar riesgo del desarrollo de lesión por fricción (LF) en adultos mayores longevos en la atención primaria de salud Métodos: Estudio descriptivo de abordaje cuantitativo. Participaron 42 adultos mayores con edad igual o superior a los 80 años. Se realizó entrevista estructurada con aplicación de formulario. Realizado el análisis descriptivo simple por medio de la frecuencia absoluta y relativa de las variables. Verificado el nivel de significancia entre los factores clínicos de mayor frecuencia y factores sociodemográficos: Edad, etnia y género, utilizando el test exacto de Fisher. Se efectuó el coeficiente de contingencia con los parámetros: c $\geq 0,750=$ asociación fuerte; 0,500 a 0,749 = asociación moderada; $\leq$,499 = asociación débil. Resultados: La edad varió de 80 a 100 años, prevaleciendo entre 80 y 85 años (59,5\%), 28 (66,7\%) del sexo femenino, 38 (90.5\%) de raza blanca y 30 (71,4\%) con primer grado incompleto. En 41 adultos mayores (97.6\%), se observaron alteraciones dermatológicas relacionadas al riesgo para LF (piel seca, mancha senil, equimosis y edema). La edad fue el factor demográfico con mayor asociación a los hallazgos clínicos ( $p=0,0397$ ). Conclusión: Frente a estos hallazgos, se vuelve imperativa la necesidad que el enfermero se capacite en conocimientos científicos, los cuales permitirán brindar cuidados capaces de controlar los factores de riesgo para el desarrollo de LF.

DESCRIPTORES: Enfermería geriátrica; Cuidados de enfermería; Atención primaria a la salud; Adulto mayor de 80 años o más; Estomoterapia.

\section{INTRODUCTION}

Friction lesions (FIs) are caused by friction, shear and/or bruising trauma, whose tension on the skin culminates in separation between the epidermis and the dermis, or both layers, leading to the formation of a flap ${ }^{1,2}$.

According to the International Skin Tear Advisory Panel (ISTAP), FIs can be classified according to the characteristics that present, with the Skin Tear Classification System being the most recently developed instrument for this purpose ${ }^{1}$. This instrument was culturally adapted and had its feasibility attested in Brazil, being called the Classification System Star - Injury by Friction, allowing to classify the FIs in categories $1 \mathrm{a}, 1 \mathrm{~b}$, $2 \mathrm{a}, 2 \mathrm{~b}$ and 3 , based on the clinical evaluation of the skin, whose staging varies from lesion with presence of a flap that can be realigned, without changes in skin color, to complete loss of the flap ${ }^{3,4}$. In most cases, the appearance of FI is associated with women, dehydration, impaired nutritional status, reduced mobility, changes in sensory and cognitive functions, dermatological alterations, previous FIs, use of adhesive strips on the skin, cardiac, pulmonary problems and neuropathic, polypharmacy, history of falls, and traumatic procedures such as blood collection. However, there is a strong relation with age, and this event is frequently present in long-lived elderly (over 80 years of age $)^{1,2,5-7}$.

Nevertheless, a systematic review has recently identified the prevalence of up to $19.5 \%$ of these injuries in the home context in different countries, with longevity being one of the most evidenced risk factors ${ }^{7}$. Certainly the susceptibility of the long-lived population to FI is due to the presence of dermatological alterations inherent in the aging process, such as reduction of endocrine secretions, involvement of collagen synthesis 
and tissue nutrition, as well as alterations in epithelial and connective tissue ${ }^{8}$ which interfere in maintaining the integrity of the skin.

In this sense, the necessity to invest in the production of knowledge, due to its reflection on the improvement of the care performed by nurses in their care practice, is especially evident, especially when it comes to the clinical evaluation of the skin of the elderly, which should occur accurately, outlined by scientifically confirmed principles 9 .

Against this problem, considering the magnitude of this phenomenon, the relevance of the present study is justified, since the identification of the risk factors for the development of FIs in the elderly will contribute to the elucidation of care practices centered in the prevention of the occurrence of this especially in the long-lived population, positively reflecting the quality of life of the elderly, as well as reducing the risk of complications and the application of financial resources to the treatment of potentially preventable skin injuries. Accordingly, to conduct this study, it was defined, as a research question, which risk factors are associated with the occurrence of FIs in long-lived elderly in the community?

\section{OBJECTIVES}

To identify the risks of developing FI in long-lived elderly in primary health care.

\section{METHODS}

Descriptive research, with a quantitative approach, developed with elderly residents in a municipality in the south of Brazil.

Thus, in order to conduct the research, inclusion criteria were defined as elderly individuals aged 80 and over, of both genders, registered in the coverage territory of the Family Health Strategy (s-HF) team of a Health Basic Unit (HBU), and/or relatives/caregivers of the elderly for those elderly who presented clinical conditions that interfere in the conduction of the dialogue with the researcher or when manifested by the necessity for participation by others. Therefore, as criteria for the representation of family members and/or caregivers, an age equal to or greater than 18 years was considered.
According to data from the Basic Attention Information System (BAIS) ${ }^{10}$, a database used by the Municipal Health Department during the period of data collection, the study population corresponded to 76 elderly. According to the sample calculation, a standard deviation of 10 units and a confidence level of $95 \%$ was used, the recommended sample size being 42 elderly, as pointed out by the Web Statistics Teaching and Learning System (SEstatNet) proposed by Nassar et al. ${ }^{11}$.

The data were obtained from July 5 to August 25,2016 , through a structured interview, at random, through a home visit performed with the support of community health agents (CHA) in the territory. During the interview, sociodemographic aspects (age, gender, ethnicity, marital status, educational level, income, besides the presence or not of caregiver) were investigated, data referring to the general health condition (nutritional aspects, drug use, presence or non-communicable chronic diseases), lifestyle (water ingestion), as well as clinical evaluation of the skin of the elderly (evaluation of edema, ecchymosis, dry skin and senile blemish).

It is added that, faced with the finding of FI, these were evaluated and classified according to the Star Rating System - Friction Injury ${ }^{3}$.

The data were transcribed using the Google® Forms software, and simple descriptive analysis was performed using the absolute (n) and relative (\%) frequencies of the variables. Thus, the level of significance between the clinical factors evidenced with the highest frequency in the sample and the socio-demographic factors (gender, age and ethnicity) were found, which constitute a risk for the occurrence of FI.

The analysis was performed using the BioEstat 5.3 software, using the chi-square or Fisher's exact test when less than 5 the confidence interval. To verify the magnitude of association between the variables, the contingency coefficient was performed with the parameters: $c \geq 0.750=$ strong association, 0.500 to $0.749=$ moderate association and $\leq 0.499=$ weak association.

It is noteworthy that, throughout the study, the criteria regarding research involving human beings were respected in accordance with Resolution of the National Health Council (NHC) 466/2012, and the study was approved by the Research Ethics Committee Federal University of Santa Catarina (UFSC) by means of the Opinion Constituted 1.619.677, CAAE: 56298116.4.0000.0121. 


\section{RESULTS}

In the area covered by s-HF, 76 elderly were identified, but 42 were interviewed through a home visit, considering what is recommended by the sample calculation. The subjects' age ranged from 80 to 100 years of age; (59.5\%), 28 (66.7\%) women, 38 (90.5\%) whites, 30 (71.4\%) had incomplete first degree and 25 (59\%, 5\%) widowers. Regarding income, 38 (90.5\%) received from one to three minimum wages.

Of the total, $24(57.2 \%)$ received professional or family care and 18 (42.9\%) had no caregiver. Regarding nutritional aspects, 23 (54.8\%) had a body mass index (BMI) within normal and 11 (26.2\%) were overweight. It is worth noting that, to define these parameters, it was considered: normal (values between 18.5 and $24.9 \mathrm{~kg} / \mathrm{m}^{2}$ ), low weight (less than $18.5 \mathrm{~kg} / \mathrm{m}^{2}$ ), overweight (between 25 and $29.9 \mathrm{~kg} / \mathrm{m}^{2}$ ) and obesity (above $\left.30 \mathrm{~kg} / \mathrm{m}^{2}\right)^{12}$.

Regarding the lifestyle, 25 (59.5\%) had an amount equal to or less than $1 \mathrm{~L} /$ day, $12(28.6 \%)$ from 1 to $1.5 \mathrm{~L} /$ day and only five above $1.5 \mathrm{~L} /$ day.

Regarding health-disease history, 33 (78.6\%) elderly had systemic arterial hypertension (SAH), nine (21.4\%) had diabetes mellitus (DM) and six (14.3\%) reported have had a cerebrovascular accident (CA) in the last year. The others had, to a lesser extent, other types of diseases, such as heart disease, arthritis, osteoporosis, among others.

Regarding the use of continuous medications, 39 (92.8\%) used at least one medication, of which, the most frequent were: 18 (46.2\%) of losartan, 12 (30.8\%) of atenolol/carvedilol, 11 (28.2\%) acetylsalicylic acid and $10(25.6 \%)$ metformin and statins. Only two elderly patients reported use of antidepressants, while the other patients reported less use of other groups of medications.

During the clinical evaluation of the skin of the participants, 41 (97.6\%) had dermatological alterations, which were the risk factors for FI: 35 (83.3\%) with dry skin, 10 (23.8\%), with senile blemish, seven (16.6\%) with edema and five (11.9\%) with ecchymosis. In addition, it is worth noting that, although they are not related to the occurrence of FI, other dermatological alterations were also evidenced during the investigation, namely dermatitis, fissures and mycosis (Table 1).
Table 1. Dermatological findings present in the sample $(n=42)$, Sao Jose, state of Santa Catarina, Brazil, 2016.

\begin{tabular}{ccc}
$\begin{array}{c}\text { Dermatological } \\
\text { findings }\end{array}$ & $\begin{array}{c}\text { Absolute frequency } \\
(\mathrm{n})\end{array}$ & $\begin{array}{c}\text { Frequência relativa } \\
(\%)\end{array}$ \\
\hline Dry skin & 35 & 83.3 \\
\hline Senile blemish & 10 & 23.8 \\
\hline Edema & 7 & 16.6 \\
\hline Ecchymosis & 5 & 11.9 \\
\hline Dermatitis & 2 & 4.7 \\
\hline Mycosis & 2 & 4.7 \\
\hline Fissures & 1 & 2.3 \\
\hline
\end{tabular}

Regarding the associated signs evaluated, 18 (42.8\%) presented dermatological alterations in the lower limbs (LL) and 19 (45.2\%) in inferior limbs (IL) and upper limbs (UL). Of the sample investigated, only two were in a bed restriction situation, 40 (95.2\%) wandering with assistance.

Regarding the presence of FI, only one (2.38\%) presented an injury, which was classified as Category 3 in the evaluation performed using the version adapted for Brazil of the Star Skin Tears Classification System ${ }^{11,13,14}$. There were also three other injuries, but of different etiologies, which are not the object of investigation of the present study.

In addition to the results presented, sociodemographic data were associated with the clinical factors observed in the study subjects.

\section{DISCUSSION}

Of the total, 41 elderly had risk factors for FI occurrence, and their relative frequency was expressed in $97.6 \%$ of the study population. Accordingly, Table 1 showed that the most frequent dermatological findings in the elderly were dry skin, senile blemish, edema and ecchymosis. Corroborating these findings, researchers pointed out that in an investigated group $(\mathrm{n}=151)$, the risk for FI was found to be two to six times greater in elderly patients with ecchymosis, senile blemish and edema ${ }^{13}$, becoming even greater in the extremities (arms and legs), since these areas are more exposed to aggressive agents ${ }^{2}$.

It is worth mentioning that the greater susceptibility of the elderly to these alterations is possibly due to the reduction of the tissues responsible for the subcutaneous padding, as well as successive vascular alterations ${ }^{14}$ caused by the aging process. 
Furthermore, as a result of physiological changes in the layers of the epidermis and dermis, which interfere with the fluid retention capacity in this age group, it is presumed that this is one of the reasons why cutaneous dryness was observed in the studied population8.

A study realized with the elderly $(=250)$ confirmed that less than half of the participants $[121(48.4 \%)]$ had ingested an amount equal to or greater than two liters of water daily ${ }^{15}$, being the parameter considered by the researchers of at least two liters and at most two and a half liters per day $^{15}$. It is added that adequate water intake is essential to reduce the chances of alterations due to dehydration ${ }^{15}$, such as skin dryness.

It should also be considered that the winter temperature, the season of the year in which the evaluation of the elderly in this study was realized, may have contributed to the appearance of this finding. Specialists report that at this time of year, there is a reduction of air humidity and temperature, which causes a decrease in body transpiration, causing skin dryness. In winter, it is very common for people to take hotter baths, which increases the reduction of the natural oiliness of the skin, decreasing the lipid mantle that retains the moisture of the skin and causing dryness and decreased resistance to the aggression of alkaline substances such as soap ${ }^{8,16}$.

Table 2 shows that only age had a significant association $(\mathrm{p}=0.0397)$ with clinical factors, but it showed a low magnitude $(c \leq 0.499)$. Thus, the findings of the present study, especially regarding dermatological alterations, are surely based on that described in the literature ${ }^{1,2,5-8}$, however, it can be inferred that the low magnitude, as far as age and well-being are concerned. as the low association of other sociodemographic variables with clinical factors may be related to the regionality of the sampling composed by the territory of only s-HF.

Regarding gender, although no significant association was observed with the clinical aspects in the analyzed sample, it is emphasized that the women can be characterized as an independent risk factor ${ }^{1}$ for the occurrence of FI. Possibly this occurs due to differences between the skin of the man and the woman, which may make it more susceptible to the occurrence of aggressions caused by shearing, contusion and/or friction.

It is worth noting that a study, whose objective was to analyze the influence of age, gender, color and BMI on the morphology and local immunity of the skin, evaluated thoracic skin fragments of autopsied individuals and concluded that the epidermis of the elderly men was more thick, as well as with a higher percentage of elastic fibers, demonstrating greater protection to injurious agents, especially mechanical trauma, in relation to women17.

The skin color also did not present a significant relation to the clinical variables, however, it should be considered that the literature suggests that the caucasian skin presents a higher risk for the occurrence of FI. Among other aspects, perhaps this fact is due to the greater vulnerability of the white skin when compared to the black one, which presents the horny layer thicker. Therefore, the increase or reduction of this layer interferes directly with the integrity of the skin, and may compromise its protection mechanism ${ }^{8,18,19}$.

Another relevant variable refers to the nutritional profile. Although only age has shown a significant association with clinical criteria, it is important to list nutritional (and water) aspects, since these are cited as modifiable risk factors ${ }^{20}$. Studies indicate, as a conclusion, independent associations between nutritional changes and the prevalence of the

Table 2. Association of sociodemographic data with clinical factors, Sao Jose, state of Santa Catarina, Brazil, 2016.

\begin{tabular}{|c|c|c|c|c|c|c|c|c|c|c|c|}
\hline \multirow{3}{*}{ Data } & \multicolumn{2}{|c|}{ Nutritional changes } & \multicolumn{6}{|c|}{ Clinical factors } & \multirow{3}{*}{$\chi^{2}$} & \multirow{3}{*}{$p$-value } & \multirow{3}{*}{ C } \\
\hline & Obese & $\begin{array}{c}\text { Low } \\
\text { weight }\end{array}$ & $\begin{array}{c}\text { Cardiovasculars } \\
\text { diseases }\end{array}$ & Polypharmacy & Edema & Dry skin & $\begin{array}{c}\text { Senile } \\
\text { blemish }\end{array}$ & Ecchymosis & & & \\
\hline & \multicolumn{8}{|c|}{ n (\%) } & & & \\
\hline \multicolumn{12}{|l|}{ Gender } \\
\hline Male & $7(50.0)$ & $1 *(7.1)$ & $10(71.4)$ & $3 *(21.4)$ & $3^{*}(21.4)$ & $12(85.7)$ & $6(42.8)$ & $2 *(14.2)$ & 6.745 & 0.455 & 0.215 \\
\hline Female & $8(28.6)$ & $2 *(7.1)$ & $25(89.2)$ & $21(75)$ & $5 *(17.8)$ & $21(75.0)$ & $9(32.1)$ & $4^{*}(14.2)$ & & & \\
\hline \multicolumn{12}{|l|}{ Age } \\
\hline$\leq 85$ & $10(40.0)$ & $1 *(4.0)$ & $20(80.0)$ & $15(60.0)$ & $7(28.0)$ & $23(92.0)$ & $14(56.0)$ & $6(24.0)$ & 14.726 & 0.039 & 0.310 \\
\hline$>85$ & $5(29.4)$ & $2^{*}(11.7)$ & $15(88.2)$ & $9(52.9)$ & $0(0.0)$ & $10(58.8)$ & $1 *(5.8)$ & $0(0.0)$ & & & \\
\hline \multicolumn{12}{|l|}{ Etnia } \\
\hline Branco & $15(39.4)$ & $1 *(2.6)$ & $33(86.8)$ & $22(57.8)$ & $8(21.0)$ & $30(78.9)$ & $13(34.2)$ & $6(15.7)$ & & & \\
\hline Negro & $0(0.0)$ & $1 *(33.3)$ & $1 *(33.3)$ & $1 *(33.3)$ & $0(0.0)$ & $2^{*}(66.6)$ & $1 *(33.3)$ & $0(0.0)$ & 18.010 & 0.206 & 0.338 \\
\hline Pardo & $0(0.0)$ & $1 *(100.0)$ & $1 *(100.0)$ & $1 *(100.0)$ & $0(0.0)$ & $1 *(100.0)$ & $1 *(100.0)$ & $0(0.0)$ & & & \\
\hline
\end{tabular}


disease, which is listed as one of the main questions related to FI risk factors ${ }^{21,22}$. Thus, given the increasing complexity of such a criterion, it is necessary to evaluate it in the immediate care scenario, in the medium and long term.

It should be noted that the presence of cardiovascular alterations in the study population, especially SAH, expressed in a considerable proportion of 33 (78.6\%) individuals, also called attention. Linked to this event, attention is paid to the occurrence of polypharmacy, which may have repercussions on cutaneous reactions due to drug interactions ${ }^{1}$. In the investigated population, it is stands out the use of antihypertensives, which have been pointed out in the literature as a predisposing class to the occurrence of $\mathrm{FI}^{1}$.

Accordingly, due to the installation of chronic conditions (such as $\mathrm{SAH}$ ), alterations in the circulatory system may occur, capable of compromising tissue perfusion and, consequently, skin resistance to injury ${ }^{23}$. Likewise, the use of antihypertensives also seems to alter tissue perfusion and compromise tissue nutrition, as pointed out in a review study ${ }^{24}$. Thus, it can be assumed that, in the investigated population, these conditions potentiate the risk for FI occurrence, due to its interference in the preservation of skin integrity.

In view of the findings of the present study, we point out, as a gap in this study, the number of the sample population and local population; however, it is emphasized that new research is already under way, covering a larger number of the target population in different realities.

\section{CONCLUSION}

The results of the present study showed that risk factors for FI were frequent in the study population, with age being the demographic factor with the highest association with clinical findings, possibly due to the great part of the alterations present in the skin of the elderly being related to the course of the aging process itself.

Among the most relevant dermatological alterations, the dry skin, the senile blemish, the edema and the ecchymosis were more frequent, being these conditions potentially avoidable through nursing care.

Gender and skin color did not present a statistically significant association in the investigated population, however, the literature suggests that these variables, independently, exert an influence on the development of FI.

Faced with these findings, it is framed the necessity for nurses to have scientific knowledge that allows them to propose care that can reflect in extinguishing, minimizing, controlling the risk factors for the development of FI, being fundamental the monitoring of conditions associated with non-modifiable, such as, for example, age, gender and ethnicity.

In view of the above, it is indispensable the professional nurse's role in primary health care as a health educator, since their care practices are capable of preventing morbidity conditions, promoting a higher quality of life for the elderly.

\section{AUTHOR'S CONTRIBUTION}

Conceptualization, Tristão FR and Girondi JBR; Methodology, Tristão FR; Girondi JBR and Lima DKS; Investigation, Tristão FR; Girondi JBR and Lima DKS; Writing - First version, Tristão FR; Girondi JBR; Hammerschmidt KAS; Soares CF; Martins T and Lima DKS; Writing - Review \& Edition, Tristão FR; Girondi JBR; Hammerschmidt KAS; Soares, CF and Martins T; Supervision, Girondi JBR.

\section{REFERENCES}

1. Leblanc K, Baranoski S, Christensen D, Langemo D, Sammon MA, Edwards K, et al. International Skin Tear Advisory Panel: a tool kit to aid in the prevention, assessment, and treatment of skin tears using a simplified classification system. Clin Manag. 2013; 26(10):459-76. https://doi.org/10.1097/01. ASW.0000434056.04071.68.

2. Clothier A. Assessing and managing skin tears in older people. Independent Nurse. 2014;12(8):23-6. https://doi. org/10.12968/indn.2014.8.23.
3. Strazzieri-Pulido KC, Santos VLCG, Carville K. Adaptação cultural, validade de conteúdo e confiabilidade interobservadores do "STAR Skin Tear Classification System". Rev Latino-Am Enfermagem. 2015;23(1):155-61. https://doi. org/10.1590/0104-1169.3523.2537.

4. Strazieri-Pulido KC. Adaptação cultural e validação do instrumento "Star Skin Tear Classification System" para a língua portuguesa no Brasil [dissertação]. São Paulo (SP): Universidade de São Paulo, Escola de Enfermagem; 2010. 
5. O'Regan A. Skin tears: a review of the literature. World Counc Enteros Ther J. 2002;22(2):26-31.

6. Oliveira GG, Neves BB, Jorge LB, Neris JCD, Rauber BR, Caberlon IC, et al. Diferenças na gravidade da queda entre idosos jovens e longevos. PAJAR. 2016;4(2):54-9. https://doi. org/10.15448/2357-9641.2016.2.26181.

7. Strazzieri-Pulido KC, Peres GRP, Campanili TCGF, Santos VLCG. Prevalência de lesão por fricção e fatores associados: revisão sistemática. Rev Esc Enferm USP. 2015; 49(4): 67480. https://doi.org/10.1590/S0080-623420150000400019.

8. Fortes TML, Suffredini IB. Avaliação da pele em idosos: revisão da literatura. J Health Sci Inst. 2014; 32(1):94-101.

9. Amante LN, Girondi JBR, Carmargo RCRM, Nascimento KC, Knihsel NS. Cuidado de enfermagem no período perioperatório: intervenções para a prática. Vol 1. Curitiba: CRV; 2015.

10. Prefeitura de São José. Relatório de Produção SIAB 2015. São José: Secretaria de Saúde; 2015.

11. Nassar SM, Wronscki VR, Ohira M, et al. SEstatNet Ensino-Aprendizagem de estatística na Web [Internet]. Florianópolis: SEstatNet; 2018 [accessed 2018 Sept 09]. Available at: http://sestatnet.ufsc.br.

12. Centro Brasileiro de Informação sobre Medicamentos. BVS Obesidade [Internet]. Brasília: Ministério da Saúde; 2018 [accessed 2018 Oct 18]. Available at: http://bvsms.saude. gov.br/bvs/dicas/215 obesidade.html/

13. Lewin GF, Newall N1, Alan JJ, Carville KJ, Santamaria NM, Roberts PA. Identification of risk factors associated with the development of skin tears in hospitalised older persons: a case-control study. Int Wound J. 2016;13(6):1246-51. https:// doi.org/10.1111/iwj.12490.

14. Hammerschmidt KSA, Tier CG, Anhaia L, Santos SSC, Paz L, Ramos AK et al. Cuidados de enfermagem na saúde do idoso. In: Cuidado de enfermagem: interfaces teóricas e práticas no ciclo vital do ser humano. Curitiba: CRV; 2015. p. 261-308.

15. Garbaccio JL, Ferreira AD, Pereira ALGG. Conhecimento e prática referidos por idosos no autocuidado com a pele no centro-oeste de Minas Gerais. Rev Bras Geriatr Gerontol 2016;19(1):45-56. https://doi.org/10.1590/18099823.2016.14237.
16. Sociedade Brasileira de Dermatologia. Cuidados com a pele no inverno [Internet]. Rio de Janeiro: SBD; 2016 [accessed 2016 Sept 09]. Available at: http://www.sbd.org.br/cuidados/ cuidados-com-a-pele-no-inverno/.

17. Oliveira LF. Avaliação morfológica e imunológica da pele de acordo com as características epidemiológicas de idosos autopsiados [dissertação]. Uberaba (MG): Universidade Federal do Triângulo Mineiro; 2011.

18. Le Blanc K, Baranoski S. Skin tears: state of the science: consensus statements for the prevention, prediction, assessment, and treatment of skin tears. Adv Skin Wound Care. 2011;24(9):2-15. https://doi.org/10.1097/01. ASW.0000405316.99011.95.

19. Bianch J. Preventing, assessing and managing skin tears. Nurs Times. 2012;108(13): 12-6.

20. LeBlanc K, Baranoski S. Skin Tears: finally recognized. Adv Skin Wound Care. 2017;30(2):62-3. https://doi.org/10.1097/01. ASW.0000511435.99585.0d.

21. Munro EL, Hickling DF, Williams DM, Bel J. Malnutrition is independently associated with skin tears in hospital inpatient setting - Findings of a 6-year point prevalence audit. Int Wound J. 2018;15(4):527-33. https://doi.org/10.1111/ iwj.12893.

22. Serra R, lelapi N, Barbetta A, Franciscis S. Skin tears and risk factors assessment: a systematic review on evidencebased medicine. Int Wound J. 2018;15(1):38-42. https://doi. org/10.1111/iwj.12815.

23. Souza NR, Freire DA, Souza MAO, Melo JTSM Santos LV, Bushatsky M. Fatores predisponentes para o desenvolvimento da lesão por pressão em pacientes idosos: uma revisão integrativa ESTIMA, Braz. J. Enterostomal Ther 2017;15(4):229-39. https://doi.org/10.5327/Z18063144201700040007.

24. Almeida AFS, Soares TSB, Abreu RNDC, Mendonça FAC, Guanabara MAO, Sampaio LRL. Influência de fármacos sobre a formação sobre a formação de úlceras por pressão: revisão integrativa. Revista Enfermagem Contemporânea. 2016;5(1):118-24. https://doi.org/10.17267/2317-3378rec. v5i1.681. 